PROC. OF JSCE

No. 339, November 1983

\title{
AN ELASTIC-PLASTIC CONSTITUTIVE MODEL OF SOILS AND ROCKS AND ITS APPLICATION TO THE FINITE ELEMENT ANALYSIS
}

\author{
By Hiroyoshi HIRAI*, Eiji YANAGISAWA** \\ and Masao SATAKE***
}

\section{INTRODUCTION}

Yield and failure criteria and stress-strain relationships for plastic behavior of soils and rocks have been studied. The members of Cambridge research group (Roscoe, Burland, Thurayrajah, Poorooshasb, Schofield, Wroth etc. ${ }^{1)-5)}$ ) developed the elastic-plastic constitutive models of soils on the basis of the associated flow rule. In order to establish the constitutive equation in general stress and strain conditions, the theories proposed by the Cambridge group were extended by many researchers (e.g., Adachi et al. ${ }^{6)}$.

Rowe $^{7)}$ proposed a stress-dilatancy theory for an assembly of particles, considering the correction for energy due to expansion. Poorooshasb et al. ${ }^{8), 9)}$ and Lade et al. ${ }^{10)}$ investigated the stressstrain relationship of sand based on the nonassociated flow rule. Mróz et al. ${ }^{11)}$ propounded an anisotropic hardening model, taking account of the anisotropic effect induced by the deformation process. Tatsuoka et al. ${ }^{12)}$ examined experimentally the yield locus of sand under various stress paths to suggest the appropriateness of the non-associated flow rule. The experimental investigation of anisotropic deformation of sand and an assembly of particles was performed by Miyamori ${ }^{13)}$, Yamada et al. ${ }^{14)}$ and Haruyama ${ }^{15)}$. Lade $^{16)}$, Vermeer ${ }^{17)}$, Nishi et al. ${ }^{18)}$ and Molenkamp $^{19)}$ proposed the double hardening models to describe the deformation characteristics of sand properly.

From the viewpoint of microscopic mechanical

* Member of JSCE, Dr. Eng., Research Associate of Civil Engineering, Tohoku University.

** Member of JSCE, Dr. Eng., Professor of Civil Engineering, Tohoku University.

*** Member of JSCE, Dr. Eng., Professor of Civil Engineering, Tohoku University. behavior, Matsuoka et al. ${ }^{20}$ proposed a failure criterion based on a spatial mobilized plane. An extension of Mohr's criterion was made by Satake ${ }^{21)}$ to take account of the influence of intermediate stress in failure state.

Akai et al. ${ }^{22}$,23) investigated the mechanical characteristics of a soft rock synthetically to propose yield functions and constitutive equations. Hirai et al. ${ }^{24), 25)}$ propounded yield functions of soft rocks on the basis of the invariants of tensors and experimental evidences.

Among techniques for analysis of mechanical behavior of soils and rocks, the method of the Finite Element (FE) has been used as an effective procedure. A number of the FE approaches based on nonlinear elastic and elastic-plastic models have been proposed (e.g., Zienkiewicz ${ }^{26}$ ) and Desai et al. ${ }^{27)}$ ). Yamada et al. ${ }^{28)}$ studied an elastic-plastic program to be applied to metals.

The first objective in the present paper is to deduce a constitutive equation in order to describe the plastic behavior of soils and rocks adequately. The second is to apply the constitutive model proposed here to FE analysis. For the above purpose, the yield function of soft rocks propounded by Hirai et al. ${ }^{24}$ ) is modified to that of soils and rocks partly. For an application of the proposed constitutive model to practical problems, the numerical calculation by the FE method is carried out for a foundation subjected to vertical loads on its surface.

\section{AN ELASTIC-PLASTIC CONSTITUTIVE EQUATION OF SOILS AND ROCKS}

Making modification of the yield function proposed by Mróz et al. ${ }^{11)}$, Hirai et al. ${ }^{24)}$ propounded a yield function which is able to express the plastic behavior of soft rocks in the following form:

$$
f=J_{2}+a J_{2}^{1 / 2}+b I_{1}^{2}+c I_{1}-d=0
$$


where $f$ is a yield function, $J_{2}$ is the second invariant of the deviatoric stress $T_{i j}^{\prime}$ defined as $J_{2}=$ $T_{i j}^{\prime} T_{i j}^{\prime} / 2, \quad I_{1}$ is the first invariant of stress $T_{i j}$ defined as $I_{1}=T_{k k}, a, b$ and $c$ are material constants and $d$ is a work-hardening parameter.

The material constants in the proposed yield function Eq. (1) are used in the range of low confining pressure where the plastic volume expansion of soft rocks occurs. It was suggested that the material constants in Eq. (1) should be newly determined under high confining pressure where the plastic volume contraction takes place. This means that the material constants in the proposed yield function Eq. (1) do not take unique values independent of the magnitude of confining pressure in order to describe the dilatancy characteristics. Since it is considered that the form of the yield function Eq. (1) is not relevant to represent the dilatancy characteristics under all range of confining pressure, a revised form of the yield function Eq. (1) will be assumed as

$$
f=J_{2}+\alpha J_{2}^{1 / 2}+\beta I_{1}^{2}+\gamma I_{1}=0
$$

where $\alpha$ and $\gamma$ are work-hardening parameters related by $\alpha=m \gamma, m$ and $\beta$ are material constants and the material constant $m$ is introduced so that Eq. (2) possesses same form as Eq. (1) at the initial yielding. Hirai et al. ${ }^{24)}$ proposed the rate of the work-hardening parameter in the form

$$
\dot{\gamma}=\phi_{1} T_{i i} \dot{E}_{j j}^{(p)} / 3+\phi_{2} T_{i j}^{\prime} \dot{E}_{i j}^{(p)}
$$

where $\phi_{1}$ and $\phi_{2}$ are material constants and $\dot{E}_{i j}^{(p)}$ are plastic strain rates. The yield function of Eq. (2) with Eq. (3) is considered to be applicable to soils and rocks whose plastic behavior depends on hydrostatic pressure, because Eq. (2) with Eq. (3) possesses necessary terms of invariants of stress and strain tensors to describe the plastic behavior of soils as well as rocks adequately. Hence, the yield function of soils and rocks proposed here is given by Eqs. (2) and (3).

Postulating that the plastic potential is identical with the yield function, Prager ${ }^{29}$ propounded an associated flow rule in the form

$$
\dot{E}_{i j}^{(p)}=\frac{1}{h} \frac{\partial f}{\partial T_{m n}} \dot{T}_{m n} \frac{\partial f}{\partial T_{i j}}
$$

where

$$
h=-\left[\frac{\partial f}{\partial E_{k l}^{(p)}}+\frac{\partial f}{\partial \gamma} \frac{\partial \gamma}{\partial E_{k l}^{(p)}}\right] \frac{\partial f}{\partial T_{k l}}
$$

Substituting Eqs. (2) and (3) into Eq. (4), we have

$$
\begin{aligned}
\dot{E}_{i j}^{(p)}= & \frac{\Lambda_{1}}{\Lambda_{2}}\left[\left\{1-m\left(J_{2}+\beta I_{1}^{2}\right) /\left(2 J_{2}^{1 / 2}\left(I_{1}+m J_{2}^{1 / 2}\right)\right)\right\}\right. \\
& \times T^{\prime} i j \\
& \left.+\left\{2 \beta I_{1}-\left(J_{2}+\beta I_{1}^{2}\right) /\left(I_{1}+m J_{2}^{1 / 2}\right)\right\} \delta_{i j}\right]
\end{aligned}
$$

where $\bar{o}_{i j}$ are called the Kronecker delta and

$$
\begin{aligned}
& \Lambda_{1}=\left\{1-m\left(J_{2}+\beta I_{1}^{2}\right) /\left(2 J_{2}^{1 / 2}\left(I_{1}+m J_{2}^{1 / 2}\right)\right)\right\} \dot{J}_{2} \\
& +\left\{2 \beta I_{1}-\left(J_{2}+\beta I_{1}^{2}\right) /\left(I_{1}+m J_{2}^{1 / 2}\right)\right\} \dot{I}_{1} \\
& A_{2}=-\left(I_{1}+m J_{2}^{1 / 2}\right)\left[\phi _ { 1 } I _ { 1 } \left\{2 \beta I_{1}-\left(J_{2}+\beta I_{1}^{2}\right)\right.\right. \\
& \left./\left(I_{1}+m J_{2}^{1 / 2}\right)\right\}+2 \phi_{2} J_{2}\left\{1-m\left(J_{2}+\beta I_{1}^{2}\right)\right. \\
& \left.\left./\left(2 J_{2}^{1 / 2}\left(I_{1}+m J_{2}^{1 / 2}\right)\right)\right\}\right]
\end{aligned}
$$

The constitutive equation in the elastic range is expressed as

$$
T_{i j}=C_{i j k l} E_{k i}^{(e)}
$$

where $C_{i j k l}$ are components of the tensor of elastic constant and $E_{k l}^{(e)}$ are components of elastic strain. As the strain rate is divisible into elastic and plastic parts in the case of infinitesimal strain, it follows that

$$
\dot{E}_{i j}=\dot{E}_{i j}^{(e)}+\dot{E}_{i j}^{(p)}
$$

Assuming Eqs. (2) and (3) and using Eqs. (4), (9) and (10), we get

$$
\dot{T}_{i j}=D_{i j k l} \dot{E}_{k l}
$$

where

$$
\begin{aligned}
D_{i j k l}= & C_{i j k l}-M_{i j k l} \\
M_{i j k l}= & C_{i j p q} \frac{\partial f}{\partial T_{p q}} \frac{\partial f}{\partial T_{m n}} C_{m n k l} \\
& /\left[-\frac{\partial f}{\partial \gamma} \frac{\partial \gamma}{\partial E_{s t}^{(p)}} \frac{\partial f}{\partial T_{s t}}+C_{s t u v} \frac{\partial f}{\partial T_{s t}} \frac{\partial f}{\partial T_{u v}}\right]
\end{aligned}
$$

Substituting Eqs. (2), (3) and $C_{i j k l}$ in Eq. (9) into Eq. (13), we can express the total stressstrain relationship Eq. (11) in terms of material constants.

\section{SOIL TESTED AND DETERMINATION OF MATERIAL CONSTANTS}

A remolded soil was sampled at the site where the slope was damaged to slide down in Shiroishi city when the 1978 Miyagiken-oki earthquake hit the north-eastern part of Japan. The soil was classified as a sandy clay loam, as shown in Fig. 1, and the physical properties are presented in Table 1. The soil was sieved by a $2000 \mu \mathrm{m}$ size sieve and transferred to oven-drying at $110^{\circ} \mathrm{C}$. The soil was thoroughly mixed with distilled water at the water-content of $21.8 \%$ over the optimum one $20.6 \%$ to increase the degree of saturation when the sample for tests was obtained by means of compaction. A test specimen which consists of ten layers was prepared by compacting with tamper in a mold and it was found from the isotropically consolidated compression test that the pressure applied to the sample is equal to $74.2 \mathrm{kPa}$. Then the sample was fixed such that the dry density $\rho_{d}=1.56 \mathrm{t} / \mathrm{m}^{3}$, the bulk density 
Table 1 Physical properties of the soil.

\begin{tabular}{lc}
\hline Liquid limit & $w_{\iota}=37.3 \%$ \\
Plastic limit & $w_{p}=20.2 \%$ \\
Plastic index & $I_{p}=16.6 \%$ \\
Specific gravity & $G_{s}=2.56$ \\
Clay fraction $(<2 \mu \mathrm{m})$ & $=12.5 \%$ \\
\hline
\end{tabular}

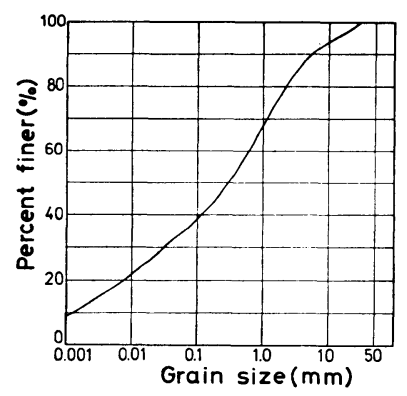

Fig. 1 Grain size distribution of the soil.

$\rho=1.90 \mathrm{t} / \mathrm{m}^{3}$ and the degree of saturation $S_{r}=$ $86.0 \%$. The sample, which is in the form of a cylinder of $12.5 \mathrm{~cm}$ in length by $5 \mathrm{~cm}$ in diameter, was set in triaxial cell and the circulation of distilled water was performed to elevate the degree of saturation in the sample. The sample was consolidated isotropically and the consolidation duration was specified to be 3 days. It was expected that the degree of saturation for samples retains over $90 \%$ at the beginning of shear tests and the back pressure of $98 \mathrm{kPa}$ was applied to all specimens.

In the case where the effective axial stress $\sigma_{1}$ and the effective radial stresses $\sigma_{2}=\sigma_{3}$ are supplied, the effective mean principal stress $p=\left(\sigma_{1}+2 \sigma_{3}\right) / 3$ and the axial difference stress $q=\left|\sigma_{1}-\sigma_{3}\right|$ are used. For strains in the triaxial condition, the volumetric strain $v=e_{1}+2 e_{3}$ and the deviatoric strain $d=2\left|e_{1}-e_{3}\right| / 3$ are adopted, where $e_{1}$ is the strain in the axial direction and $e_{3}$ is that in the radial direction. The compressive stresses and strains are taken to be positive. Fig. 2 shows the initial and subsequent yield loci given by Eq. (2) in $(p, q)$ plane. Fig. 3 shows the relationship between the stress $q$ and the strain $d$ for the stress path ABCDE. The sample is isotropically consolidated to $p=98 \mathrm{kPa}$ at point $\mathrm{A}$ and the curve OFA corresponds to the initial yield surface. The axial stress $\sigma_{1}$ increases up to point $B$ and decreases up to point $C$ under the constant radial stresses $\sigma_{2}=\sigma_{3}$. Then the isotropical consolidation $p=137 \mathrm{kPa}$ is subjected to the sample at point $\mathrm{D}$ and the axial stress is increased up to point $\mathrm{E}$ under the constant radial

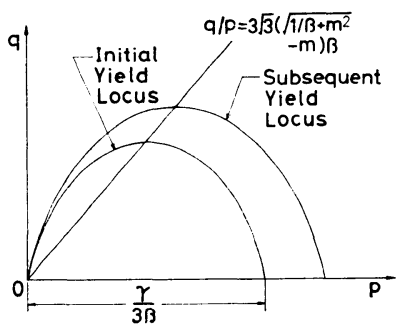

Fig. 2 Initial and subsequent yield loci.

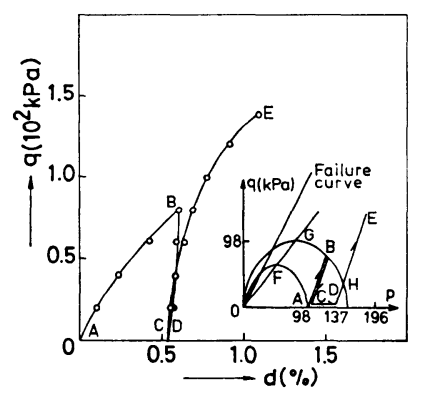

Fig. 3 Relationship between $q$ and $d$ for a stress path.

stresses. It is found from Fig. 3 that yielding occurs in the neighborhood of $q=40 \mathrm{kPa}$ between points $\mathrm{D}$ and $\mathrm{E}$. This implies that yielding may take place at point $\mathrm{H}$ which corresponds to the intersection of the stress path DE and the subsequent yield surface OGB. The elastic shear modulus $G$ is determined from the experimental result in the elastic range between points $B$ and $\mathrm{C}$ as follows:

$$
G=49 \mathrm{MPa}
$$

This elastic modulus will be used to divide the plastic strain from the total strain.

The relationship between the ratio of plastic strain rates $\dot{v}^{p} / \dot{d}^{p}$ and the ratio of stresses $q / p$ in the triaxial condition can be determined by use of Eq. (6). Applying Eq. (6) to triaxial conditions, we have

$$
x=3.3^{1 / 2} \frac{y^{2}+6.3^{1 / 2} m \beta y-27 \beta}{-m y^{2}+6.3^{1 / 2} y+27 m \beta}
$$

where $x=-\dot{v}^{p} / \dot{d}^{p}, \quad y=q / p, \quad v^{p}$ and $d^{p}$ are the volumetric and deviatoric plastic strains. The material constants $m$ and $\beta$ are determined from experimental data plotted in $(x, y)$ plane. Fig. 4 shows relationships between $x$ and $y$ for triaxial compression tests $\mathrm{A}$ and $\mathrm{B}$ and triaxial extension tests $\mathrm{C}$ and $\mathrm{D}$ under the constant- $p$ condition. Applying the data in Fig. 4 to Eq. (15), we get

$$
m=-1.66, \quad \beta=0.0302
$$




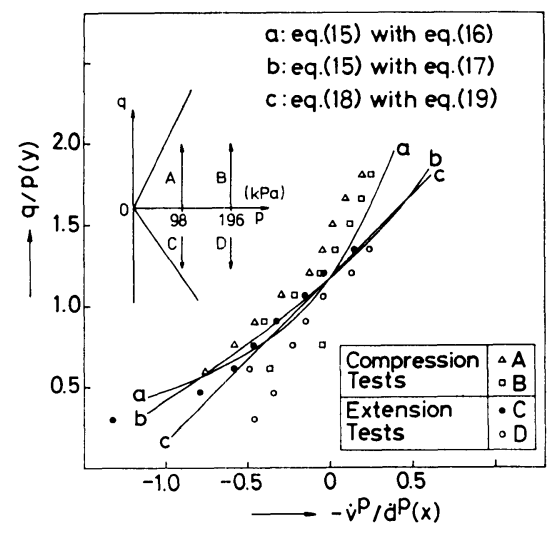

Fig. 4 Relationships between $q / p$ and $\dot{v}^{p} / \dot{d}^{p}$ for triaxial compression and extension tests.

The curve a in Fig. 4 represents Eq. (15) with Eq. (16). Consider the case where the material constant $m$ is neglected in the stress-strain relationship given by Eq. (15). In this case, applying the data in Fig. 4 to Eq. (15), we obtain

$$
m=0, \quad \beta=0.052
$$

where the material constant $\beta$ is treated as a constant value in the present paper though the parameter $\beta$ is considered to depend on the $b$ value which will be mentioned in Eq. (27). The curve $b$ in Fig. 4 corresponds to Eq. (15) with Eq. (17), which is the same form as the relationship proposed by Burland ${ }^{3)}$.

The curve $c$ in Fig. 4 represents the constitutive relation proposed by Roscoe et al. ${ }^{1)}$ in the following form:

$$
x=y-M
$$

where $M$ is a material constant and is determined from the data in Fig. 4 as

$$
M=1.18
$$

and where $M$ is treated as a constant value in the present paper, though it may be dependent on the $b$-value. The stress-strain relationship Eq. (18) is derived from the plastic potential

$$
g=J_{2}^{1 / 2} / I_{1}-M /\left(3.3^{1 / 2}\right) \ln \left|I_{1} / I_{0}\right|=0
$$

where $I_{0}$ is a work-hardening parameter. The curve $\mathrm{c}$ in Fig. 4 describes the experimental data better than the other ones $a$ and $b$ in the range where the plastic volume contraction occurs. It is found, however, that the curve a predicts the experimental results of the soil best in the three curves in the range where the plastic volume expansion appears. The stress-strain relationship given by Eq. (15) was employed for soft rocks in order to describe the dilatancy characteristic under low confining pressure. Sub-

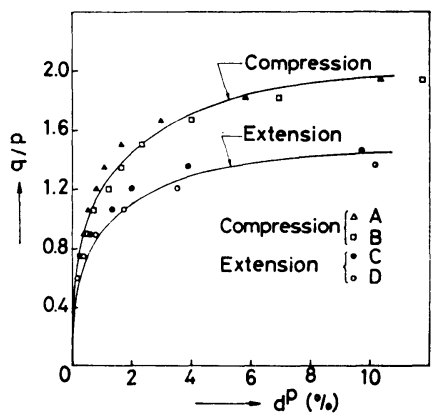

Fig. 5 Relationships between $q / p$ and $d^{p}$ for triaxial compression and extension tests.

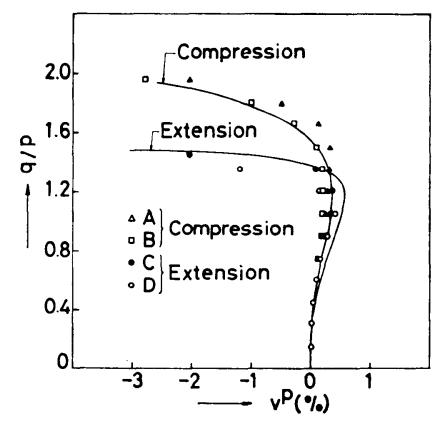

Fig. 6 Relationships between $q / p$ and $v^{p}$ for triaxial compression and extension tests.

sequently, it is considered that Eq. (15) can be adopted as an adequate stress-strain relationship of soils and rocks in the range where the plastic volume expansion occurs. Furthermore, it is suggested that the relation of Eq. (18) predicts the behavior in the range where the plastic volume contraction is observed.

Let us consider the material constants $\phi_{1}$ and $\phi_{2}$ in the work-hardening parameter $\gamma$ given by Eq. (3). In the triaxial constant- $p$ test, the following equations are obtained from Eq. (6).

$$
\begin{aligned}
& \dot{d}^{p} / \dot{y}=4 y^{2} /\left[9 \phi_{1}\left\{27 \beta+(2 n-1) y^{2}\right\}\right] \cdots \cdots \cdots(2) \\
& \dot{v}^{p} / \dot{y}=2\left(27 \beta-y^{2}\right) y /\left[9 \phi_{1}\left\{27 \beta+(2 n-1) y^{2}\right\}\right]
\end{aligned}
$$

where $n=\phi_{2} / \phi_{1}$. Fig. 5 shows relationships between the deviatoric plastic strain $d^{p}$ and the ratio of stresses $q / p$ for four stress paths of $\mathrm{A}, \mathrm{B}$, $\mathrm{C}$ and $\mathrm{D}$ in Fig. 4. For the triaxial compression tests of $A$ and $B$, applying the data shown in Fig. 5 to Eq. (21), we have

$$
\phi_{1}=25.1, \quad n=0.334
$$

On the other hand, the behavior in triaxial extension tests of $\mathrm{C}$ and $\mathrm{D}$ is somewhat different from that in triaxial compression ones of $\mathrm{A}$ and $\mathrm{B}$. For the triaxial extension tests, applying the 
data of stress paths of $\mathrm{C}$ and $\mathrm{D}$ shown in Fig. 5 to Eq. (21), we have

$$
\phi_{1}=17.1, \quad n=0.170
$$

The theoretical curve of Eq. (21) with Eq. (23) for triaxial compression tests and that of Eq. (21) with Eq. (24) for triaxial extension ones are represented in Fig. 5. Fig. 6 shows relationships between the volumetric plastic strain $v^{p}$ and the ratio of stresses $q / p$ for four stress paths of $\mathrm{A}$, B, C and D in Fig. 4. One curve drawn in Fig. 6 corresponds to Eq. (22) with Eq. (23) for triaxial compression tests and the other is Eq. (22) with Eq. (24) for triaxial extension ones. It is seen from Figs. 5 and 6 that the theoretical equations of Eqs. (21) and (22) can describe the experimental data for triaxial compression and extension tests adequately.

In view of data given by Miyamori ${ }^{13)}$, Yamada et al. ${ }^{14)}$ and Haruyama ${ }^{15)}$, it may be suggested that the parameters $n$ and $\phi_{1}$ for triaxial compression tests take maximum values and those for triaxial extension ones have minimum values in genuine triaxial tests. Subsequently, for the parameters $n$ and $\phi_{1}$ in the general stress condition, it may be assumed simply that

$$
\begin{aligned}
& n=\left(n_{e}-n_{c}\right) b+n_{c} \\
& \phi_{1}=\left(\phi_{1 e}-\phi_{1 c}\right) b+\phi_{1 c}
\end{aligned}
$$

where

$$
\begin{aligned}
& b=\left(\sigma_{2}-\sigma_{3}\right) /\left(\sigma_{1}-\sigma_{3}\right) \\
& 3^{1 / 2} \tan \theta=\frac{2 \sigma_{2}-\sigma_{1}-\sigma_{3}}{\sigma_{1}-\sigma_{3}}=2 b-1
\end{aligned}
$$

where $\sigma_{1}, \sigma_{2}$ and $\sigma_{3}$ are the major, intermediate and minor principal stresses respectively, the anti-clockwise direction $\theta$ is measured from the $\xi$-axis perpendicular to $\sigma_{2}{ }^{\prime}$-axis, as shown in Fig. 7, $n_{c}$ and $\phi_{1 c}$ are material constants $n$ and $\phi_{1}$ for triaxial compression tests, $n_{e}$ and $\phi_{1 e}$ are those for triaxial extension ones and they are given by Eqs. (23) and (24) respectively. Fig. 7 shows a stress state in three principal stresses $\sigma_{1}, \sigma_{2}$ and $\sigma_{3}$ and the stress state can be designated by invariants $I_{1}, J_{2}$ and the angle $\theta$ in $\pi$-plane

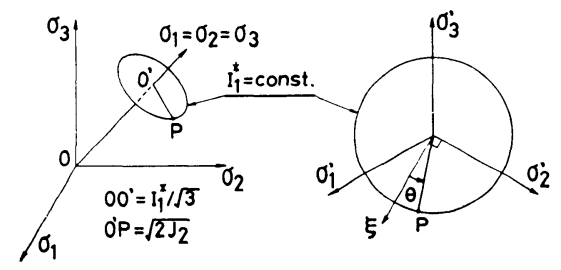

Fig. 7 Stress state in stress space and on $\pi$ plane.
( $I_{1}=$ const. $)$, where $\sigma_{1}^{\prime}, \sigma_{2}^{\prime}$ and $\sigma_{3}^{\prime}$ are the deviatoric stresses. Eqs. (25) and (26) mean that the parameters $n$ and $\phi_{1}$ are functions of $b$-value, which designates the stress state on the $\pi$-plane.

Let us calculate the stress-strain relationships for various $b$-values on the basis of the constitutive equation of Eq. (6) by using Eqs. (25) and (26). The equivalent plastic strain rate $\dot{\boldsymbol{\varepsilon}}^{p}$ is defined as follows ${ }^{30)}$ :

$$
\dot{\varepsilon}^{p}=\left\{\frac{2}{3} \dot{E}_{i j}^{\prime(p)} \dot{E}_{i j}^{(p)}\right\}^{1 / 2}
$$

where $\dot{E}_{i j}^{\prime(p)}$ are the deviatoric plastic strain rates. The equivalent stress $\sigma$ is expressed by the second invariant of the deviatoric stress in the form ${ }^{30}$ )

$$
\sigma=\left\{3 J_{2}\right\}^{1 / 2}
$$

By use of Eqs. (6), (29) and (30), the relationship between the equivalent plastic strain and the ratio of the equivalent stress to the first invariant of stress is written in the following form for the constant- $I_{1}$ test.

$$
\dot{\varepsilon}^{p}=4 z^{2} \dot{z} /\left[3 \phi_{1}\left\{3 \beta+(2 n-1) z^{2}\right\}\right]
$$

where $z=\sigma / I_{1}^{*}$ and $I_{1}^{*}=\sigma_{1}+\sigma_{2}+\sigma_{3}$. Integrating Eq. (31) with respect to $z$ leads to

$$
\begin{aligned}
\varepsilon^{p}= & \frac{1}{\phi_{1}(1-2 n)}\left[2 \sqrt{\frac{\beta}{3(1-2 n)}}\right. \\
& \left.\times \ln \left(\frac{\sqrt{3 \beta}+\sqrt{1-2 n} z}{\sqrt{3 \beta}-\sqrt{1-2 n z}}\right)-\frac{4}{3} z\right]
\end{aligned}
$$

Substituting Eqs. (17), (25) and (26) into Eq. (32), we obtain the equivalent stress-strain relationship for various $b$-values. Fig. 8 shows the stressstrain relationships drawn on the plane $\left(\varepsilon^{p}, \sigma / I_{1}^{*}\right)$ on the basis of the theoretical equation (32).

From Eqs. (6) and (30), the relationship between the volumetric plastic strain $v^{p}$, and the ratio of the equivalent stress to the first invariant of stress, $\sigma / I_{1}^{*}$, is represented in the following form for the constant- $I_{1}$ test.

$$
\dot{v}^{p}=2\left(3 \beta-z^{2}\right) z \dot{z} /\left[\phi_{1}\left\{3 \beta+(2 n-1) z^{2}\right\}\right]
$$

Integration of Eq. (33) with respect to $z$ leads to

$$
v^{p}=\frac{1}{\phi_{1}(1-2 n)}\left[\frac{6 n \beta}{1-2 n} \ln \left\{\frac{3 \beta-(1-2 n) z^{2}}{3 \beta}\right\}+z^{2}\right]
$$

Substituting Eqs. (17), (25) and (26) into Eq. (34), we obtain the relationship between the volumetric plastic strain and the ratio of stresses for various $b$-values. Fig. 9 represents the stressstrain relationships drawn on the plane $\left(v^{p}, \sigma / I_{1}^{*}\right)$ by use of the theoretical equation (34). As the $b$-value increases from zero to one, the slope of the stress-strain curve for each $b$-value becomes gentle in the range of small strain and the failure 


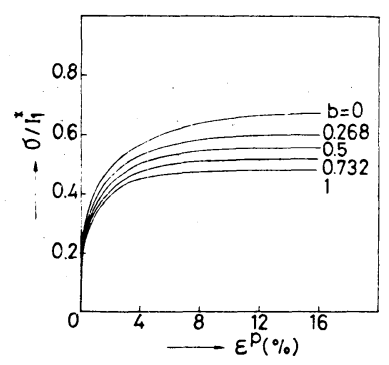

Fig. 8 Relationships between $\sigma / I_{1}^{*}$ and $\varepsilon^{p}$ for $b$-values.

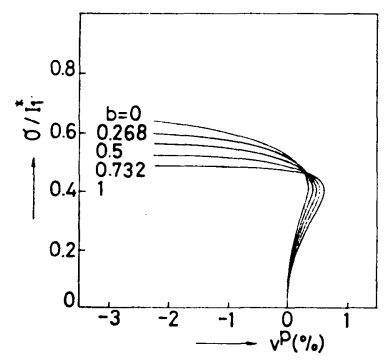

Fig. 9 Relationships between $\sigma / I_{1}^{*}$ and $v^{p}$ for $b$-values.

stress decreases gradually, as shown in Figs. 8 and 9. This trend is same as the experimental data given by Miyamori ${ }^{13)}$, Yamada et al.14) and Haruyama ${ }^{15)}$. Subsequently, it is considered that the theoretical equations (32) and (34) may predict the stress-strain relationship for various $b$-values adequately.

The failure criterion may be expressed by three invariants of stress $I_{1}, J_{2}$ and $J_{3}$, where $J_{3}=T_{i j}^{\prime} T_{j k}^{\prime} T_{k l}^{\prime} / 3$ is the third invariant of deviatoric stress. Matsuoka et al. ${ }^{20)}$ propounded a failure criterion on the basis of a spatial mobilized plane as follows:

$$
I_{1} I_{2} / I_{3}=k
$$

where $I_{2}$ and $I_{3}$ are second and third invariants of stress respectively and $k$ is a constant. This criterion explains the experimental results in different three principal stresses fairly well. It would be reasonable to express the failure criterion by use of two parameters in order to describe two failure states of triaxial compression and extension tests accurately. Then Ogawa et al. ${ }^{31)}$ proI posed a failure criterion of soils in the form

$$
F=J_{3}+\zeta J_{2} I_{1}+\eta I_{1}^{3}=0
$$

where $\zeta$ and $\eta$ are material constants. The failure curve in $(p, q)$ plane in triaxial compression tests performed here is given by

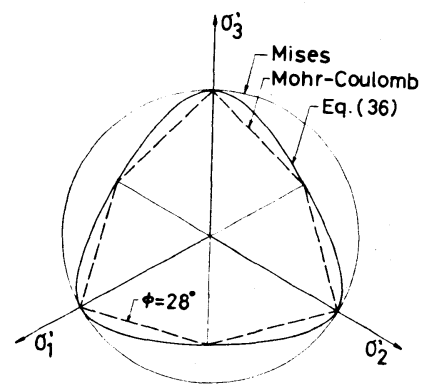

Fig. 10 Failure criteria of a soil on $\pi$-plane.

$$
q / p=1.98
$$

The failure curve in triaxial extension tests is expressed by

$$
q / p=1.46
$$

Substitution of Eqs. (37) and (38) into Eq. (36) leads to

$$
\left.\begin{array}{l}
\zeta=-0.439 \\
\eta=0.0432
\end{array}\right\}
$$

The failure surface given by Eq. (36) with Eq. (39) on $\pi$-plane of $I_{1}^{*}=3$ is shown in Fig. 10. The failure criteria proposed by Mises and MohrCoulomb are together represented in Fig. 10 and the Mohr-Coulomb's criterion corresponds to the case where the angle of internal friction is $\phi=28^{\circ}$. The failure criterion expressed by Eq. (36) with Eq. (39) forms almost same curve as that proposed by Matsuoka et al. ${ }^{20)}$

\section{ANALYTICAL PROCEDURE BY THE FINITE ELEMENT METHOD}

The total stress-strain relationship of Eq. (11) is represented in matrix form, i.e.,

$$
\{\Delta T\}=[D]\{\Delta E\}
$$

where $\{\Delta T\}$ is the matrix of stress-increments, the elastic-plastic stress-strain matrix $[D]$ is symmetric and $\{\Delta E\}$ is the matrix of strainincrements. For the two dimensional plane strain problem in rectangular Cartesian coordinates, Eq. (40) is expressed in the explicit form as

$$
\left\{\begin{array}{l}
\Delta T_{11} \\
\Delta T_{22} \\
\Delta T_{12} \\
\Delta T_{33}
\end{array}\right\}=\left[\begin{array}{lll}
D_{11} & D_{12} & D_{13} \\
D_{12} & D_{22} & D_{23} \\
D_{13} & D_{23} & D_{33} \\
D_{41} & D_{42} & D_{43}
\end{array}\right]\left\{\begin{array}{l}
\Delta E_{11} \\
\Delta E_{22} \\
\Delta \gamma_{12}
\end{array}\right\}
$$

where $\Delta \gamma_{12}=2 \Delta E_{12}$ denotes the engineering strain and 


$$
\begin{aligned}
D_{11}=\lambda & +2 G-\left\{2 G T_{11}^{\prime}+(3 \lambda+2 G)\right. \\
& \left.\times\left(\beta I_{1}-J_{2} / I_{1}\right)\right\}^{2} / A \\
D_{12}=\lambda & -\left\{2 G T_{11}^{\prime}+(3 \lambda+2 G)\left(\beta I_{1}-J_{2} / I_{1}\right)\right\} \\
& \times\left\{2 G T_{22}^{\prime}+(3 \lambda+2 G)\left(\beta I_{1}-J_{2} / I_{1}\right)\right\} / A \\
D_{13}=- & 2\left\{2 G T_{11}^{\prime}+(3 \lambda+2 G)\left(\beta I_{1}-J_{2} / I_{1}\right)\right\} \\
& \times G T_{12} / A \\
D_{22}=\lambda & +2 G-\left\{2 G T_{22}^{\prime}+(3 \lambda+2 G)\right. \\
& \left.\times\left(\beta I_{1}-J_{2} / I_{1}\right)\right\}^{2} / A \\
D_{23}=- & 2\left\{2 G T_{22}^{\prime}+(3 \lambda+2 G)\left(\beta I_{1}-J_{2} / I_{1}\right)\right\} \\
& \times G T_{12} / A \\
D_{33}=G & -4\left(G T_{12}\right)^{2} / A \\
D_{41}=\lambda & -\left\{2 G T_{33}^{\prime}+(3 \lambda+2 G)\left(\beta I_{1}-J_{2} / I_{1}\right)\right\} \\
& \times\left\{2 G T_{11}^{\prime}+(3 \lambda+2 G)\left(\beta I_{1}-J_{2} / I_{1}\right)\right\} / A \\
D_{42}=\lambda & -\left\{2 G T_{33}^{\prime}+(3 \lambda+2 G)\left(\beta J_{1}-J_{2} / I_{1}\right)\right\} \\
& \times\left\{2 G T_{22}^{\prime}+(3 \lambda+2 G)\left(\beta I_{1}-J_{2} / I_{1}\right)\right\} / A \\
D_{43}=- & 2\left\{2 G T_{33}^{\prime}+(3 \lambda+2 G)\left(\beta I_{1}-J_{2} / I_{1}\right)\right\} \\
& \times G T_{12} / A \\
A=- & I_{1}\left\{\phi_{1} I_{1}\left(\beta I_{1}-J_{2} / I_{1}\right)+2 \phi_{2} J_{2}\right\} \\
& +4 G J_{2}+3\left(\beta I_{1}-J_{2} / I_{1}\right)^{2}(3 \lambda+2 G)
\end{aligned}
$$

where $\lambda$ is Lamé's constant.

The strain-increments $\{\Delta E\}$ at any point can be determined with the displacement-increments $\{\Delta u\}$ known at all points within the element in the form

$$
\{\Delta E\}=[B]\{\Delta u\}
$$

where the matrix $[B]$ is defined in Zienkiewicz's book $^{26)}$. The stiffness matrix of the element is represented by

$$
[k]=[B]^{T}\left[D^{\prime}\right][B] t \Omega
$$

where $\left[D^{\prime}\right]$ is the elastic-plastic stress-strain matrix $[D]$ except for $D_{41}, D_{42}$ and $D_{43}$ in Eq. (41), $t$ is the thickness of the element and $\Omega$ is the area of the triangle. The stiffness matrices of elements, $[k]$, are assembled to form the matrix of the whole region, $[K]$. The overall matrix $[K]$ relates the nodal load-increment $\{\Delta L\}$ to the nodal displacement-increment $\{\Delta u\}$ in the form

$$
\{\Delta L\}=[K]\{\Delta u\}
$$

Yamada et al. ${ }^{28)}$ proposed an approach for elastic-plastic analysis by means of the finite element method. This technique is used for materials such as metals obeying the equation of Prandtl-Reuss on the basis of the von Mises' yield criterion. Although the program given by Yamada et al. is not relevant to soils and rocks whose plastic behavior depends on hydrostatic pressure, the thought in this program is considered to be helpful to the procedure of elastic-plastic analysis of soils and rocks.

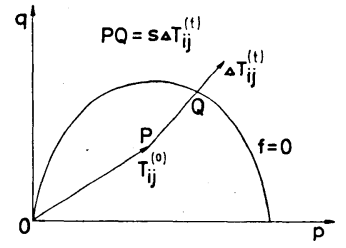

Fig. 11 Determination of a yield element.

Some details of the analytical procedure of the problem for soils and rocks are represented briefly in what follows.

1. Calculate elastic displacements at the nodes, and then elastic strains, stresses at each element for the body force of soils or rocks. The stress obtained here is employed as the initial value denoted by $T_{i j}^{(0)}$ in the problem.

2. Solve the stiffness equation of Eq. (45) for a test load-increment $\left\{\Delta L^{(t)}\right\}$ and obtain the nodal displacement-increment $\left\{\Delta u^{(t)}\right\}$. Then calculate stress-increment $\Delta T_{i j}^{(t)}$ and strainincrement $\Delta E_{i j}^{(t)}$ at each element. Obtain the elastic solution in the first cycle in the program and the elastic-plastic solution after the second cycle. One cycle corresponds to the load-increment process to reduce an element to yield.

3. Scale up or down the stress-increment $\Delta T_{i j}^{(t)}$ for all elastic elements in order to find an initial yield element in the first cycle. As shown in Fig. 11, the following equation may be satisfied to reduce an element to first yield in all elastic elements.

$$
f\left(T_{i j}^{(0)}+s \Delta T_{i j}^{(t)}, \gamma_{0}\right)=0
$$

where $f=f\left(T_{i j}, \gamma\right)$ is given by Eq. (2) with Eq. (17), $s$ is a scale factor and $\gamma_{0}$ is the value of $\gamma$ at initial yielding. Solving Eq. (46) with respect to $s$ leads to

$$
\begin{aligned}
& s=\left[-\left(Q+2 \beta S V+\gamma_{0} V\right)+\left\{\left(Q+2 \beta S V+\gamma_{0} V\right)^{2}\right.\right. \\
& \left.\left.-4\left(R+\beta V^{2}\right)\left(P+\beta S^{2}+\gamma_{0} S\right)\right\}^{1 / 2}\right] \\
& \text { I }\left\{2\left(R+\beta V^{2}\right)\right\}
\end{aligned}
$$

where

$$
\begin{aligned}
& P=T_{i j}^{\prime(0)} T_{i j}^{\prime(0)} / 2 \\
& Q=T_{i j}^{\prime(0)} \Delta T_{i j}^{(t)} \\
& R=\Delta T_{i j}^{(t)} \Delta T_{i j}^{(t)} / 2 \\
& S=T_{k k}^{(0)} \\
& V=\Delta T_{k k}^{(t)}
\end{aligned}
$$

The scale factor which brings an element to first yield is designated by the minimum value among scale factors of Eq. (47) calculated for all elastic elements. An appropriate test load-increment $\left\{\Delta L^{(a)}\right\}$ to reduce the elastic element of the minimum scale factor $s_{\min }$ to yield is specified by $\left\{\Delta L^{(a)}\right\}=s_{\min }\left\{\Delta L^{(t)}\right\}$. The element having $s_{\min }$ 
is treated as a plastic element from now on, the remainder being left in the elastic state for the first cycle and in the elastic or plastic state after the second cycle. After the second cycle in the program, the stress $T_{i j}^{(0)}$ in Eq. (46) is replaced by the stored stress in step 4 and scale up or down the stress-increment $\Delta T_{i j}^{(t)}$ due to test loadincrement $\left\{\Delta L^{(t)}\right\}$ in order to find a subsequent yield element.

4. Calculate the nodal displacement, stress and strain-increments for the load-increment $\left\{\Delta L^{(a)}\right\}$ and add to the present displacement, stress and strain. Store the results.

5. Check whether the work-hardening parameter $\gamma=-\left(J_{2}+\beta I_{1}^{2}\right) / I_{1}$ at the present cycle is greater than that at the previous cycle for all elements. If greater, the work-hardening continues. If smaller, the elastic state remains or unloading occurs. Return to step 2.

Let us consider a foundation subjected to uniform loads $p$ of $2 a$ in width in the two dimensional plane strain problem. According to Zienkiewicz et al. ${ }^{32}$, the finite element mesh is divided as shown in Fig. 12 and the foundation is assumed to be made of the soil experimented in section 3. It is assumed that Poisson's ratio $\nu=$ 0.45 and the density $\rho=1.9 \mathrm{t} / \mathrm{m}^{3}$. If the foundation is made of the soil isotropically consolidated with the effective mean principal stress of $196 \mathrm{kPa}$, the work-hardening parameter of Eq. (3) at initial yielding is assumed to be $\gamma_{0}=30.6 \mathrm{kPa}$. The constitutive equation of Eq. (6) describes fully the plastic behavior of soils. Although the parameters $n$ and $\phi_{1}$ in the work-hardening parameter $\gamma$ of Eq. (3), represented by Eqs. (25) and (26) respectively, are dependent on the state of stress or $b$-value, the value given by Eq. (23) will be adopted simply as constant parameters in the present analysis in order to investigate the effectiveness of computational procedure to

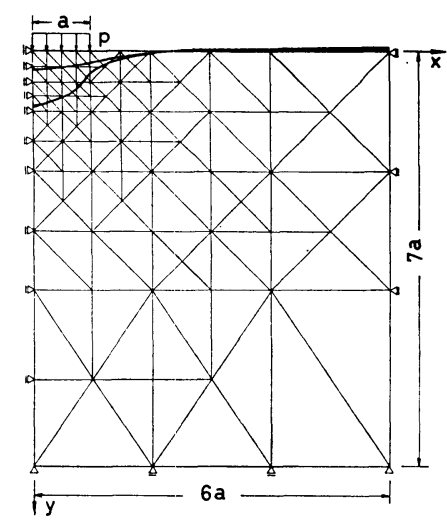

Fig. 12 Finite element mesh and settlement curves. apply the proposed constitutive model to the finite element method.

The two curves in Fig. 12 show the settlement on the surface of foundation for two loads stages, $p=225 \mathrm{kPa}$ and $p=325 \mathrm{kPa}$. The maximum value of settlement $v_{\max }$ at the point $x=0$ is calculated as follows: $v_{\max }=3.26 \times 10^{-3} a$ for $p=225 \mathrm{kPa}$ and $v_{\max }=9.25 \times 10^{-3} a$ for $p=325$ $\mathrm{kPa}$.

Fig. 13 shows the load-settlement curves for three nodes $x=0,0.5 a$ and $a$ on the surface of foundation. Since the soil which constitutes the foundation is initially isotropically consolidated to $196 \mathrm{kPa}$, it is suggested that the initial yielding of elements under loaded area will occur at the vertical load near $p=196 \mathrm{kPa}$. It is noticed from Fig. 13 that the initial yielding for curves of $x=0$ and $x=0.5 a$ takes place at the vertical loads $p=208 \mathrm{kPa}$ and $p=227 \mathrm{kPa}$ respectively, and settlement proceeds rapidly after yielding occurs.

Fig. 14 shows yield elements for two load stages, $p=225 \mathrm{kPa}$ and $p=325 \mathrm{kPa}$. It is seen that plastic elements appear on the surface of foundation because the mean principal stress is very small and the state of stresses is near the original point in stress space. The plastic parts spread downward circularly due to large stresses under the loaded position. It is of interest that elements possessing the state beyond the failure curve increase as the vertical load increases. The sequence of these failure elements may develop into the sliding surface.

In what follows, the figures of stresses are depicted for the case of external load $p=325 \mathrm{kPa}$. Fig. 15 shows the distribution of normalized stress in the horizontal direction $x, \sigma_{x}$. The contour line of stress $\sigma_{x}$ spreads diagonally from the top left-hand corner to the bottom righthand corner. Fig. 16 represents the distribution of normalized stress in the vertical direction $y$, $\sigma_{y}$. Since the gravitational force is taken into account in the present analysis, the magnitude

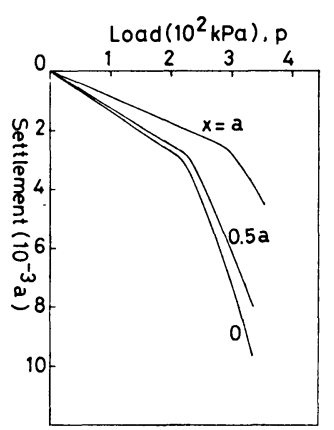

Fig. 13 Load-settlement curves on the surface of foundation. 


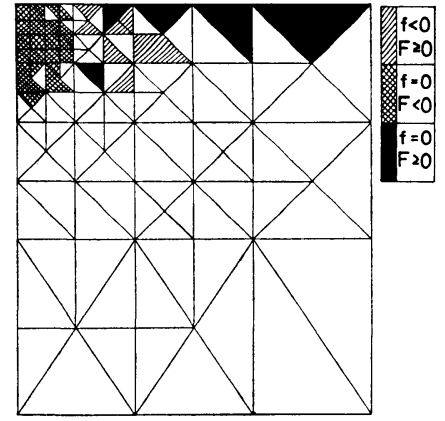

(a) $\mathrm{p}=225 \mathrm{kPa}$

Fig. 14 Yield and failure elements.

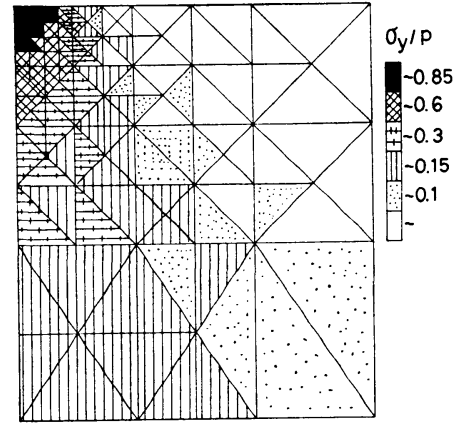

Fig. 16 Distribution of stress $\sigma_{\nu}$.

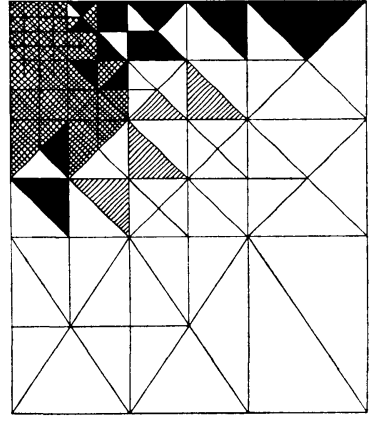

(b) $\mathrm{P}=325 \mathrm{kPa}$

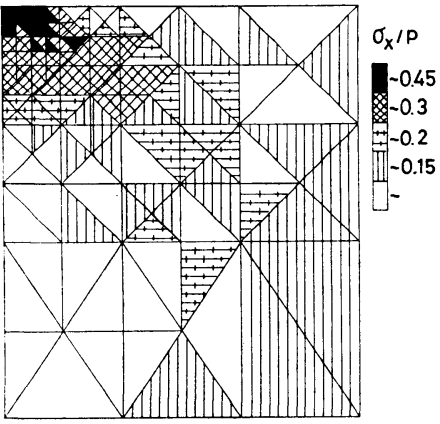

Fig. 15 Distribution of stress $\sigma_{x}$.

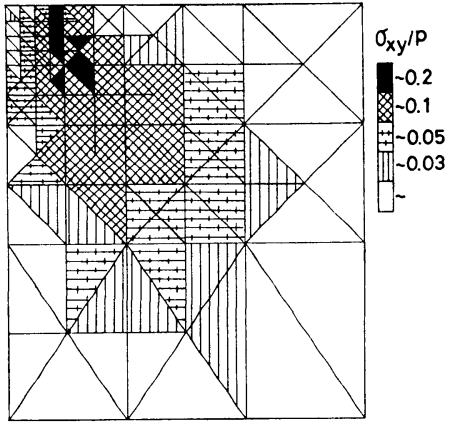

Fig. 17 Distribution of stress $\sigma_{x y}$.

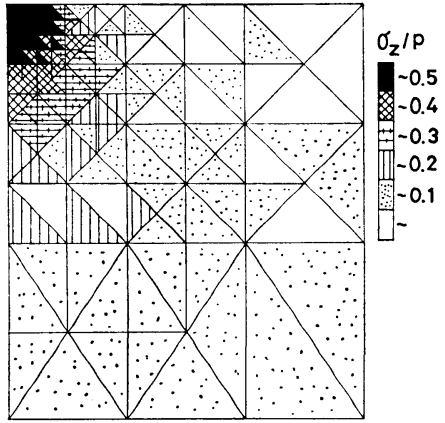

Fig. 18 Distribution of stress $\sigma_{z}$. of $\sigma_{\nu}$ is somewhat different from that of neglecting the gravitational force. Fig. 17 shows the normalized shear stress $\sigma_{x y}$ and the contour line of $\sigma_{x y}$ expands downward circularly from the edge of loaded area. Fig. 18 shows the normalized stress $\sigma_{z}$ in the direction vertical to the $x-y$ plane. It is found that the gradient of stress $\sigma_{z}$ is steeper than those of other stresses. Although the distribution of stresses in linear elastic problems is independent of the degree of external loads, the solution of elastic-plastic problems depends on the magnitude of external forces.

\section{CONCLUDING REMARKS}

A new simple form of yield function of soils and rocks was proposed by modifying an old yield function propounded for soft rocks. Since the new yield function as well as the old one is considered to be useful to rocks, attention was focussed on the effectiveness of the new yield function to describe the plastic behavior of soils in the present paper. The accuracy of the constitutive equation derived from the proposed yield function was evaluated by comparing predicted and measured plastic strains for triaxial tests performed for a soil.
On the basis of the proposed constitutive model, the problem of a foundation subjected to uniform loads was analyzed by the finite element method. It was found that the analytical procedure follows yield regions adequately with the increase of external load. It was suggested that the computational procedure by the constitutive equation propounded in the present paper is very applicable to the finite element analysis.

\section{REFERENCES}

1) Roscoe, K. H., A. N. Schofield and A. Thurayrajah: Yielding of Clays in States Wetter than Critical, Géotechnique, Vol. 13, pp. 211 240, 1963.

2) Roscoe, K. H. and H. B. Poorooshasb: A Theoretical and Experimental Study in Triaxial Compression Tcsts on Normally Consolidated Clays, Géotechnique, Vol. 13, pp. 12 38, 1963.

3) Burland, J. B.: The Yielding and Dilatation of Clay, Correspondence, Géotechnique, Vol. 15, pp. 211 214, 1965.

4) Roscoe, K. H. and J. B. Burland: On the Generalized Stress-Strain Behavior of 'Wet' Clay, Engineering Plasticity (ed. Heyman, J. and F. A. Leckie), Cambridge University Press, pp. 535 609, 1968. 
5) Schofield, A. N. and C. P. Wroth: Critical State Soil Mechanics, McGraw-Hill, London, 1968.

6) Adachi, T. and M. Okano: A Constitutive Equation for Normally Consolidated Clay, Soils and Foundations, Vol. 14, No. 4, pp. 55 73, 1974.

7) Rowe, P. W.: The Stress-Dilatancy Relation for Static Equilibrium of an Assembly of Particles in Contact, Proceedings of the Royal Society of London, Ser. A, Vol. 269, pp. 500 527, 1962.

8) Poorooshasb, H. B., I. Holubec and A. N. Sherbourne: Yielding and Flow of Sand in Triaxial Compression, Part I, Canadian Geotechnical Journal, Vol. 3, No. 4, pp. 179 190, 1966.

9) Poorooshasb, H. B., I. Holubec and A. N. Sherbourne: Yielding and Flow of Sand in Triaxial Compression, Parts II and III, Vol. 4, No. 4, pp. 377 398, 1967.

10) Lade, P. V. and J. M. Duncan: Elastoplastic Stress-Strain Theory for Cohesionless Soil, American Society of Civil Engineers, Journal of the Geotechnical Division, GT10, pp. 1037 1053, 1975.

11) Mróz, Z., V. A. Norris and O. C. Zienkiewicz: Application of an Anisotropic Hardening Model in the Analysis of Elasto-Plastic Deformation of Soils, Géotechnique, Vol. 29, No. 1, pp. 1 34, 1979.

12) Tatsuoka, F. and K. Ishihara: Yielding of Sand in Triaxial Compression, Soils and Foundations, Vol. 14, No. 2, pp. 63 76, 1974.

13) Miyamori, T.: Deformation and Strength of Sand in Three Dimensional Stress State, Proceedings of Japan Society of Civil Engineers, No. 255, pp. 81 91, 1976, (in Japanese).

14) Yamada, $Y$. and $K$. Ishihara: Anisotropic Deformation Characteristics of Sand under Three Dimensional Stress Conditions, Soils and Foundations, Vol. 19, No. 2, pp. 79 94, 1979.

15) Haruyama, M.: Anisotropic DeformationStrength Characteristics of an Assembly of Spherical Particles under Three Dimensional Stresses, Soils and Foundations, Vol. 21, No,. 4 pp. $41 \sim 55,1981$.

16) Lade, P. V.: Elasto-Plastic Stress-Strain Theory for Cohesionless Soil with Curved Yield Surfaces, International Journal of Solids and Structures, Vol. 13, pp. 1019 1035, 1977.

17) Vermeer, P. A.: A Double Hardening Model for Sand, Géotechnique, Vol. 28, No. 4, pp. $413 \sim 433,1978$.

18) Nishi, K. and Y. Esashi: Stress-Strain Relationships of Sand Based on Elasto-Plasticity Theory, Proceedings of Japan Society of Civil Engineers, No. 280, pp. 111 122, 1978.

19) Molenkamp, F.: An Elasto-Plastic Double Hardening Model (MONOT), Delft Soil Mecha- nics Laboratary, CO-218595, 1980.

20) Matsuoka, H. and T. Nakai: Stress-Deformation and Strength Characteristics of Soil under Three Different Principal Stresses, Proceedings of Japan Society of Civil Engineers, No. 232, pp. $59 \sim 70,1974$.

21) Satake, M.: A Proposal of New Yield Criterion for Soils, Proceedings of Japan Society of Civil Engineers, No. 189, pp. 79 88, 1971, (in Japanese).

22) Akai, K., T. Adachi and K. Nishi: ElastoPlastic Behaviors of Soft Sedimentary Rock (Porous Tuff), Proceedings of Japan Society of Civil Engineers, No. 271, pp. 83 95, 1978, (in Japanese).

23) Akai, K., T. Adachi and K. Nishi: Time Dependent Characteristics and Constitutive Equations of Soft Sedimentary Rock (Porous Tuff), Proceedings of Japan Society of Civil Engineers, No. 282, pp. 75 87, 1979, (in Japanese).

24) Hirai, H. and M. Satake: Proposal of a Yield Function and Description of Plastic Behavior of Soft Rocks, Proceedings of Japan Society of Civil Engineers, No. 320, pp. 159 164, 1982.

25) Hirai, H., M. Satake and E. Yanagisawa: Proposal of a Time-Dependent Yield Function and Characteristics of Yielding of Soft Rocks, Proceedings of the Japan Society of Civil Engineers, No. 334, pp. 155 162, 1983.

26) Zienkiewicz, O. C.: The Finite Element Method in Engineering Science, McGraw-Hill, London, 1971.

27) Desai, C. S. and J. F. Abel: Introduction to the Finite Element Method, Van Nostrand Reinhold, NewYork, 1972.

28) Yamada, Y., N. Yoshimura and T. Sakurai: Plastic Stress-Strain Matrix and Its Application for the Solution of Elastic-Plastic Problems by the Finite Element Method, International Journal of Mechanical Science, No. 10, pp. 343 354, 1968.

29) Prager, W.: Recent Developments in the Mathematical Theory of Plasticity, Journal of Applied Physics, Vol. 20, pp. 235 241, 1949.

30) Hill, R.: The Mathematical Theory of Plasticity, Oxford Press, 1950.

31) Ogawa, S., S. Mitsui and O. Takemurei: An Experimental Study on Influence of Intermediate Principal Stress on Mechanical Properties of Sands, Proceedings of 29th Annual Meeting of Japan Society of Civil Engineers, Part 3, pp. $49 \sim 50,1974$ (in Japanese).

32) Zienkiewicz, O. C., S. Valliappan and I. P. King: Elasto-Plastic Solutions of Engineering Problems 'Initial Stress,' Finite Element Approach, International Journal for Numerical Method in Engineering, Vol. 1, pp. 75 100, 1969.

(Received January 20, 1983) 
土木学会論文報告集 第 339 号

\section{土質・岩質材料の弾塑性構成モデルと 有限要素解析への応用}

（平井弘義／柳沢栄司／佐武正雄）

昭和 58 年 11 月

軟岩を始めとする岩質材料は拘束圧の大きさにより， ダイレタンシー特性が異なっている. このような力学特 性を表現するために以前提案された降伏関数は拘束圧の 大小に応じて分けて考える必要があり，拘束圧の大きさ に依存しない唯一の形を有していなかった。そこでその ような問題を解決するために, 新しい形の降伏関数が軟 岩などの岩質材料に対して提案されている. この提案さ れた降伏関数は塑性挙動が静水圧に依存し得る岩質材料 のみならず土質材料に対しても有用なものと考えられ る. それは土質,岩質材料の塑性挙動を記述するために, 応力テンソルとひずみテンソルに関して必要な不変量を 有しているからである. 本研究では土質, 岩質材料に対 して提案された降伏関数から求められる構成式について 検討を行う．軟岩などの岩質材料については，以前提案 された構成式と異なり拘束圧の大小にかかわらず，ダイ レタンシー特性を適切に表現し得る点が今回提案されて いる構成式の特徴といえる。しかし塑性挙動の記述とい う点では両者はほぼ同様な形を呈しているので, 本論文 では提案された新しい降伏関数の土質材料への適用性に 焦点が向けられている.

まず土質材料に対して三軸圧縮，三軸伸張試験を行い， 体積塑性ひずみ增分と偏差塑性ひずみ増分の比および軸 差応力と平均主応力の比をそれぞれ座標とする 2 次元グ ラフを描き，その力学特性を表現するために提案された 構成式について検討を行い，その中に含まれる2つの材 料定数の意味について考察を行っている.この場合 $1 つ$ の材料定数を除くと Burland によって提案された構成式 に帰着し得るが，2つの材料定数を用いることによって より適切に実験結果を表現し得ることが示されている.
また近似的には Burland の式が適用され得ると考えら れ，本論文ではさらに硬化パラメーターに含まれる材料 定数の意味について検討を進めてゆくため, Burland の 式を理論の簡単化のために採用している.

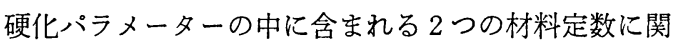
して，土の三軸圧縮と三軸伸張試験の実駼結果に対する それぞれの值を求めている。この場合提案された構成式 は土質材料の実験結果を適切に表現し得ることが示され ている. 1つの材料定数の力学的意味については破壊状 態と变相状態 (phase-transformation state) に関する力学 特性に関連させて考察し, 塑性仕事の関係についても示 唆されている. また他の 1 つの材料定数は応力ーひずみ 曲線の勾配と関係ゔけられ得ることが示されている.

次に三主応力がすべて異なる場合の既往の実験結果を 参考にして，硬化パラメーターの中に含まれる材料定数 は応力状態を表わすパラメーターすなわち $\mathrm{b}$ 值の関数 として考えられ得ることが示されている. 多くの実験で は b 值はあらかじめ指定され得るので, 材料定数は唯一 に決定されることになる。このような場合に関して, 三 軸圧縮および伸張試験より得られる実験結果は一般のb 值=一定試験に抢ける 2 つの極限状態に相当し, b 值を 変えた場合の応力ーひずみ関係が提案された構成式を用 いて説明されている.この得られた応力ーひずみ関係式 は $\mathrm{b}$ 值が異なる場合の既往の試験結果を適切に表現し得 ることが示唆されている。

最後に提案された構成式に基づいて，有限要素法を用 いた土質, 岩質材料の解析手法が提案されている. 降伏 要素の判定については金属材料について山田が提案した 手法を, 本論文では, 塑性変形が静水圧に依存し得る土 質, 岩質材料に対して適用している. 応用例としては一 定分布荷重を受ける半無限体基礎について解析を行って いる.ここでは荷重一沈下曲線について弾性域から塑性 域に至る状況が曲線の勾配変化として示されている。 た塑性要素，破壞要素について荷重増加に伴うそれらの 厷がり状態も明らかにされている，応力状態については 弾塑性解析の場合，外荷重の大きさに依存してその分布 が変化し得ることが示されている。 